\title{
Policies for Small and Medium Sized Enterprises' Development in the Republic of Moldova: Results and Challenges
}

\author{
Lica ERHAN and Tatiana GAUGAS \\ Academy of Economic Studies of Moldova, Chisinau, Republic of Moldova
}

Correspondence should be addressed to: Lica ERHAN; lica.erhan@ase.md

Received date:24 November 2020; Accepted date: 5 September 2021; Published date: 26 January 2022

Academic Editor: Petra Kecskés

Copyright (C) 2022. Lica ERHAN and Tatiana GAUGAS. Distributed under Creative Commons Attribution 4.0 International CC-BY 4.0

\begin{abstract}
Small and medium sized enterprises (SMEs) are the main force for economic growth, but at the same time an extremely vulnerable sector, which constantly needs support from the state. Thus, one of the basic tasks in the state regulation of the activity of this sector involves the development of policies aimed to support small and medium business. This study attempted to analyze promoted policies for the development of SMEs in the Republic of Moldova, focusing on achievements, but also on the remaining deficiencies in their development. We noticed that the policies promoted over the years have resulted in a series of positive achievements, such as increasing the contribution of the SMEs to Gross Domestic Product, multiplying the number of SMEs and the workforce employed in these enterprises. At the same time, based on this analytical approach, it has been found that leading challenges for SMEs development include heavy regulatory framework, lack of diverse financing sources and high costs of infrastructure, global competition and lack of technologic and managerial capabilities. Further, this research includes recommendations for overcoming these challenges and identifying requirements for the long-run development of the SMEs. The current study has been drawn up, using the official data offered by the National Bureau of Statistics, Organization for Small and Medium-Sized Enterprises Sector Development, the Ministry of Economy from the Republic of Moldova, World Bank reports Doing Business, International Monetary Fund (IMF) reports, Organization for Economic Cooperation and Development (OECD) reports, and the most recent references in this field of research.
\end{abstract}

Keywords: SMEs, policies, challenges, development.

Cite this Article as: Lica ERHAN and Tatiana GAUGAS (2022)," Policies for Small and Medium Sized Enterprises' Development in the Republic of Moldova: Results and Challenges ", Journal of Innovation \& Business Best Practice, Vol. 2022 (2022), Article ID 706025,

DOI:10.5171/2022.706025 


\section{Introduction}

Small and medium sized enterprises (SMEs) play an extremely important role in modern economies. They create jobs, enhance competition, contribute to technological change, increase the use of domestic resources and products and are a source of innovation. They are considered as the most dynamic and vulnerable businesses in the global economy and are critical to any country's development as they play a significant role in human development, poverty reduction, and sustainable economic growth. SMEs account for 90 percent of businesses and employ about 60 percent of the workforce in the world (Munro, 2013).

According to Technical Assistance report provided by IMF in 2021, Moldova is among the smallest, poorest, and least competitive European countries, in part due to systemic corruption and political instability. Despite averaging around 4 percent in recent decades, output growth has been insufficient to raise living standards significantly, with GDP per capita remaining among the lowest in Europe. While corruption and political instability are factors affecting the economic growth of many emerging markets, these factors are often cited as the most problematic for doing business in Moldova. In these current economic conditions from Moldova, SMEs start their activity on a background of an economic uncertainty, and it becomes obvious that their successful development and even their existence on the market depends on the results of the support policies promoted by the state. The most important point is that SMEs benefit the economy due to the potential for the use of local resources such as the utilization of local raw materials, mobilization of local savings, provision of the opportunities for self-employment and opportunity for training semi-skilled workers through apprenticeship (Asare, et al., 2015).

Starting from this reality, the current research is dedicated to the topic of small business development in the Republic of
Moldova, pointing out policies promoted by the state for supporting SMEs. We noticed that the policies promoted over the years have resulted in a series of positive achievements, such as: increasing the contribution of the SMEs to GDP, multiplying the number of SMEs and the workforce employed in these enterprises. At the same time, based on this analytical approach, it has been found that leading challenges for SMEs development include heavy regulatory framework, lack of diverse financing sources and high costs of infrastructure, global competition and lack of technologic and managerial capabilities. Further, this research includes requirements for overcoming these challenges and identifying solutions for the long-run development of the SMEs. An analysis of secondary data resources has been carried out in this research, using scientific methods, in particular logical methods, such as comparative analysis, synthesis, induction and deduction. In the study, we used official data offered by the National Bureau of Statistics, Organization for Small and Medium-Sized Enterprises Sector Development, the Ministry of Economy from the Republic of Moldova, World Bank reports Doing Business, International Monetary Fund (IMF) reports, Organization for Economic Cooperation and Development (OECD) reports, and the most recent references in this field of research. From a methodological point of view, this article uses a series of analysis methods often used in national and international practice in the study of SMEs in order to research and anticipate their evolution towards a balanced and sustainable development. Thus, to achieve the goal of this research, first off all we started an analysis of the current situation in the field of SMEs from the Republic of Moldova. Small and medium enterprises' (SMEs) sector in the Republic of Moldova during the last 30 years of independence has developed qualitatively and quantitatively. In 2020, SMEs constitute $98.6 \%$ of the total number of enterprises $185.4 \%$ of them were micro enterprises, $10.9 \%$ small enterprises and only $2.3 \%$ medium-sized enterprises); assure $60.1 \%$ of all employed persons; 
contribute with $39.3 \%$ in the total number of sales. The revenues from sales of SMEs in 2020 were 150111.1 million lei, or $39.3 \%$ per economy. The revenues of small and medium-sized enterprises increased in all areas. Taking into consideration the social function of SMEs that is expressed through creating places of work, we can mention that the number of the persons who were engaged in small and medium enterprises in 2020 was - 316.8 thousand persons, which constitutes $60.1 \%$ from the total number of employees.

Therefore, we can state that SMEs, as a social economic phenomenon, have not become yet a key link in the development of national economy. The micro enterprises represent the largest share of companies in the SMEs sector (85.4\%), however, their contribution to employment, and to turnover, is quite modest. In addition, the largest share of SMEs from Moldova is still in the wholesale and retail trade. The innovation capacity of SMEs in the Republic of Moldova is low. As a result, innovation impact on national economy is reduced as well. Moldova has a low share of staff engaged in high technological intensity production. The following reasons determine us to have a close look on the policies that have been applied during the years in the Republic of Moldova that aimed to support SMEs development.

\section{Discussions}

The SMEs Development Strategy 20122020 is the main strategic document guiding policy developments in the area of small business in Moldova. The strategic mission of this public policy document was to create a favorable business environment and to promote entrepreneurial culture for supporting SMEs. In order to accomplish this strategic mission, the Government of the Republic of Moldova has outlined the following priority policies/directions:

- adjusting the regulatory framework to the needs of SMEs development;

- improving SMEs access to finance;

- promoting skills and entrepreneurial culture;
- increasing the competitiveness of SMEs;

- facilitating business partnerships and development of SMEs in the regions.

The first policy aimed to adjust the regulatory framework to the needs of SMEs development. The existence of an effective regulatory framework that would allow SMEs to operate and develop in an appropriate competitive environment is fundamental to the growth of this sector. The Republic of Moldova made considerable efforts in order to renew the legal framework that supports the activity of SMEs.

Although the National Development Strategy "Moldova 2020" is the main strategic economic policy document, the EU-Moldova Association Agreement, the Deep and Comprehensive Free Trade Area created in 2014, have been important in shaping policy developments in Moldova, stimulating the speed and depth of economic and financial policy reforms. Moldova has recently developed a new National Development Strategy, "Moldova 2030", which is aligned with both EUMoldova Association Agreement and the United Nations'2030 Agenda for Sustainable Development. The new Strategy does not have specific targets for SME development, but many of the priority actions highlighted in the document aim to support entrepreneurship.

A serious contribution in the regulation of the SMEs activity was brought by the changes of the fiscal system and the economic liberalization reform, undertaken in the last years. According to the Doing Business report, Moldova made some serious efforts in simplifying the procedure to start a business through promoting the following incentive policies:

- simplifying business registration requirements by cutting the time needed to start a business by half;

- removing the requirement to register with the Social Security Fund and the requirement to file separately for registration with the National Statistics Bureau; 
- implementing the "one-stop shop" principle, meant to minimize the contacts of entrepreneurs with state officials;

- legalizing the capital - which involved the voluntary declaration of undeclared property held by citizens and legal entities residents of the Republic of Moldova both in the country and abroad, with the payment of 5 percent legalization fee;

- implementing electronic asset declaration system, without the need to waste time with personal visits to the authorities. This system was introduced in January 2018, following the e-integrity information system developed with World Bank support, and allows asset declarations to be submitted directly online. Electronic services were diversified, so companies can submit via on-line platform their Financial Statements and other documents applying the electronic signature.

By all these policies, Moldova managed to remove redundant bureaucratic requirements on enterprises, expand egovernment services and implement programmes to alleviate barriers to doing business. These reforms have been reflected in the 2020 World Bank Doing
Business report, which ranks Moldova $48^{\text {th }}$, up from 63 $3^{\text {rd }}$ in 2015. Despite these support policies taken in recent years and the obtained results, there are still many administrative-bureaucratic barriers that impose unjustified additional costs for local entrepreneurs who want to start or expand their business. For example, in recent years, Moldova made starting a business more costly by increasing the cost for company registration. More than this, according to IMF report (2021) for Moldova, despite having legal and institutional frameworks largely in place, Moldova continues to suffer from significant corruption and governance vulnerabilities. The rule of law in Moldova is weak, with poor implementation of legal and regulatory frameworks. The justice system is widely recognized as being ineffective and susceptible to corruption and capture. These issues also appear to be the main reasons for poor protection of property rights and contract enforcement, as well as inconsistent application of the commercial legal framework. Weak rule of law in Moldova is cited as a deterrent to foreign direct investment and development of SMEs. In Table 1, we present some of the remained challenges in this field of regulatory framework as well as the necessary requirements for SMEs development.

Table 1: Challenges and requirements of SMEs development in the field of regulatory framework

\begin{tabular}{|c|c|}
\hline Challenges & Requirements \\
\hline $\begin{array}{l}\text { - frequent inspections and controls of } \\
\text { SMEs; } \\
\text { - lack of tax facilities exclusively for SMEs; } \\
\text { high cost for registration and liquidation } \\
\text { proceeds; } \\
\text { - administrative barriers. }\end{array}$ & 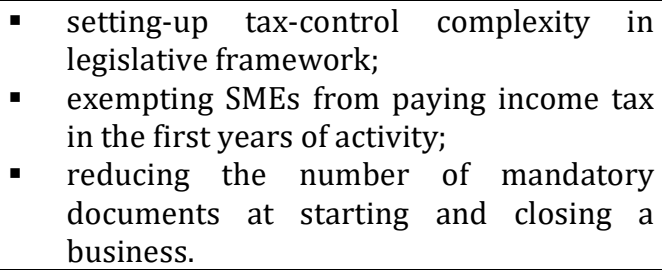 \\
\hline
\end{tabular}

We are strongly convinced that all these requirements/proposals, to improve the regulatory framework of SMEs, will have the impact of reinvesting saved funds and increasing investor confidence in the business environment in the Republic of Moldova.
The second policy aimed to improve SMEs access to finance. The measures that have been taken to expand the access to financial means of SMEs in the Republic of Moldova, in terms of state policies and programs, have been considerable. The financial sector has seen increased levels of stability and international investor interest following the IMF review. A 2018 law on 
"non-bank credit institutions" has brought various forms of alternative finance under one regulatory umbrella, strengthening, for example, leasing regulations.

Banks represent the primary source of financing for local SMEs in Moldova. SMEs support programs are offered through virtually every major bank, though they tend to be both donor-funded and targeting a very specific segment or use. However, commercial banks often show a reserved attitude, and do not have the courage to lend SMEs in the necessary volume, motivated both by the financial instability characteristic of these companies and by the low quality of the financial plans presented by companies.

Government support schemes also include interest rate subsidies, state programmes which are generally considered to be a less sustainable mechanism. At the same time, the access of SMEs to financial support from the state through the state programs must be ensured on transparent and nondiscriminatory conditions. European practice has resorted a financial limit on the support that a company could benefit from. In the Republic of Moldova, there is a rule that an SME that has received financial support in some programs will not be eligible for others. However, this process is not sufficiently monitored, and small and medium-sized business agents often practice hiding the fact that they have benefited from some other programs, resorting to scams in order to attract as much non-reimbursable financial support as possible. In this situation, we consider it is necessary to create a database at national level, which can be accessed by all financial support donors, and which will enter the data of those companies that have received support and are no longer eligible to attract for a certain period of time. Monitoring the process of nondiscriminatory allocation of financial support will contribute positively to a proportional distribution of aid per sector. A challenge, however, will be both setting the appropriate limit of financial support and the period for which no other aid will be granted.

Another achievement, taken from the successful international practice is the presence in the Republic of Moldova of two credit guarantee funds. The main advantage of guarantee funds is that they make it possible, on the one hand, to reduce the risk of bank lending and, on the other hand, to attract the maximum possible level of financial resources for SMEs. The main challenges and requirements in the field of limited financial access of SMEs are presented in table 2 .

Table 2: Challenges and requirements of SMEs development in the field of financial access

\begin{tabular}{|c|c|}
\hline Challenges & Requirements \\
\hline $\begin{array}{l}\text { - only } 1 / 3 \text { from all the credits offered by } \\
\text { the bank sector belong to SMEs sector; } \\
\text { about } 80 \% \text { from the total number of the } \\
\text { financial application rejected by the bank } \\
\text { were caused by lack of guarantee; } \\
\text { lack of innovative instruments of finance, } \\
\text { such as: venture capital or business } \\
\text { angels. } \\
\text { lack of state funding for SMEs innovations }\end{array}$ & $\begin{array}{l}\text { - supporting of the national net-work of } \\
\text { guaranteed funds for SMEs; } \\
\text { creating a national database on the } \\
\text { beneficiaries of SME financial support } \\
\text { programs; } \\
\text { adopting the necessary legal framework } \\
\text { for the activity of venture capital funds. }\end{array}$ \\
\hline
\end{tabular}

We hope that the infiltration of the nominated proposals/requirements in the Moldovan financial environment will substantially contribute to facilitating the access of SMEs to finance resources.
The third policy aimed to promote entrepreneurial skills and culture. The lack of information and advisory assistance infrastructure and the development of entrepreneurial potential, especially at regional level, insufficient staff 
qualification, low level of training and culture of entrepreneurship in SMEs, continue to be an obstacle to business development. Banks and non-bank credit institutions have indicated that one of the reasons for the refuse of credits or loans requested by SMEs is the low quality of the business plans presented by them. In this context, it becomes obvious that SME owners need to transfer knowledge in order to grow their business.
Promoting the entrepreneurial culture is a strategic objective for which our country still has great reserves and potential that must be exploited. The central role is played by the state in paying more attention to investment in knowledge. The main challenges and requirements of SMEs development in the field of entrepreneurial skills and culture are presented in table 3 .

Table 3: Challenges and requirements of SMEs development in the field of entrepreneurial skills and culture

\begin{tabular}{|c|c|}
\hline Challenges & Requirements \\
\hline $\begin{array}{l}\text { - insufficient qualification of personnel, low } \\
\text { level of skills and culture of SMEs } \\
\text { entrepreneurial spirit; } \\
\text { - lack of an efficient consulting system in } \\
\text { the domain of education and developing } \\
\text { business in SMEs sector; } \\
\text { lack of a program about the competitive } \\
\text { evaluation in the domain of } \\
\text { entrepreneurial activity. }\end{array}$ & $\begin{array}{l}\text { - expanding consulting and training } \\
\text { services for managers and entrepreneurs } \\
\text { within SME support organizations; } \\
\text { improving cooperation between } \\
\text { academia, research centers and SMEs; } \\
\text { developing business incubators and } \\
\text { promoting their launch in higher } \\
\text { education institutions from the country. }\end{array}$ \\
\hline
\end{tabular}

We hope that the nominated proposals/requirements will have a positive impact both at the microeconomic level - by creating a critical mass of entrepreneurs who will have the knowledge and skills needed to start a business, and at the macroeconomic level by gradually changing entrepreneurial mentality in society.

The fourth policy aimed to increase the competitiveness of SMEs. Evidence shows that small businesses that are aware that they have to create continually, evaluate and successfully exploit their new ideas, are more likely to survive and prosper in the competitive global economy. The development of the SMEs in the Republic of Moldova in terms of innovations will increase the competitiveness of the small business and, consequently, will promote the intensification of growth rates, market expansion, export development, increasing sales and thus profit. Competitiveness based on innovation must become a priority for national SMEs. In the last years, a number of public-private projects and international financing have been launched in the Republic of Moldova, meant to contribute to the increase of the innovation and competitiveness capacities of SMEs. Several business incubators have been opened and the process has been extended to creating a network of business incubators. Industrial parks were opened and feasibility studies were carried out for their regional expansion. This support infrastructure is extremely important for SMEs, as it contributes to their efficient activity, offering them opportunities to launch and expand their business. SMEs have been identified as innovation-friendly, as they may encourage a corporate culture that allows participation, flexibility, networking, inclusion and experimentation across the organisation. Challenges of the external environment faced by SMEs could lead to an innovative response to establish a competitive advantage. Small firms can innovate in response to two factors: appropriate business environment and limited growth conditions. The more diverse and compromised the environment faced by SMEs, the higher the level of proactive innovative behaviors. However, experts found that in cases where small businesses do not have the resources, innovation could suffer. 
The current legal framework from Moldova does not stimulate enough innovation activity. The innovation capacity of SMEs in Moldova is low. Subsequently, the innovation impact on national economy is rather small. In addition, although the Code on science and innovation stipulates that research and development funding should be at least 1 percent of GDP annually, this provision is not respected and budgetary funding is below this amount. Both economic theory and empirical evidence support the idea that innovation plays a vital role in increasing productivity on a sustainable basis. For these reasons, in many countries, there is an active policy on encouraging innovation. In table 4 are presented the main challenges and requirements of SMEs development in the field of competitiveness.

Table 4: Challenges and requirements of SMEs development in the field of SMEs competitiveness

\begin{tabular}{|l|l|}
\hline \multicolumn{1}{|c|}{ Challenges } & \multicolumn{1}{|c|}{ Requirements } \\
\hline - low level of adaption of SMEs to the \\
$\begin{array}{l}\text { European standards of quality; } \\
\text { low level of elaboration and absorption of } \\
\text { innovation; } \\
\text { undeveloped infrastructure for } \\
\text { supporting business. }\end{array}$ & $\begin{array}{l}\text { supporting innovation and improvement } \\
\text { of SMEs access to new technologies; } \\
\text { supporting the introduction of quality } \\
\text { standards and systems of quality } \\
\text { management; } \\
\text { extending and developing business } \\
\text { incubators and industrial parks. } \\
\text { applying product, process or marketing } \\
\text { innovation strategies }\end{array}$ \\
\hline
\end{tabular}

The last policy aimed to facilitate business partnerships and development of SMEs in the regions. Law no. 179 - XVI, regarding the public-private partnership, does not contain special regulations regarding the access of SMEs to public contracts. In Moldova, the facilities granted to all economic activities, as a whole, do not particularly favor SMEs. Analyzing the situation in the field of small and medium business, we can easily see that there is still a long way to go until the state fulfills all the facilities required by small and medium business. Here, we state the idea that the owners of small and medium-sized businesses must also take part in the discussion and adoption of the most important framework concerning the activity of these enterprises. Currently, SMEs in the Republic of Moldova face a lack of an effective mechanism for cooperation, coordination and consultation with central and local public authorities. We find the cause especially in the reduced institutional capacities of the business associations - organizations empowered to represent the interests of the local entrepreneurs in the public-private dialogue. Meanwhile, the density of SMEs in Chisinau capital of the Republic of Moldova reaches about 70 percent of the total number of SMEs in the country. The created situation clearly showed the Government of the Republic of Moldova the need to promote an intense regional development policy. A significant role in this direction belongs to the support programs of SMEs, which are primarily addressed to entrepreneurs in the rural areas of the country, who want to start or develop a business. At the same time, the regional development of SME support infrastructure can contribute to a more balanced development and emergence of small and medium-sized businesses in the regions. The main challenges and requirements of SMEs development in the field of business partnership are presented in table 5. 
Table 5: Challenges and requirements of SMEs development in the field of business partnership

\begin{tabular}{|l|l|}
\hline \multicolumn{1}{|c|}{ Challenges } & \multicolumn{1}{|c|}{ Requirements } \\
\hline - $\begin{array}{l}\text { the development of partnership in } \\
\text { business is at a starting stage; } \\
\text { lack of cooperation between academic } \\
\text { staff and business; } \\
\text { week regional development of SMEs. }\end{array}$ & $\begin{array}{l}\text { developing public-private partnerships in } \\
\text { research; } \\
\text { developing clusters, as a base of } \\
\text { entrepreneurial partnership. } \\
\text { establishing analytical tools for assessing } \\
\text { the most stringent regional needs of the } \\
\text { sector. }\end{array}$ \\
\hline
\end{tabular}

\section{Conclusions}

The world economy is developing very quick, generating major changes in the structure of all regional economies. For SMEs in the Republic of Moldova, this reality imposes the need to develop and implement policies, which would take into account the particularities of the local business environment, giving them the opportunity to obtain competitive advantages and superior results. A developed SMEs sector can reconfigure the economy of the Republic of Moldova, both through massive employment opportunities and through competitiveness and dynamism.

In substantiating the above reflections, we conclude that the policies that have been promoted so far to support and develop SMEs in Moldova have not yet managed to provide sufficient motivation for the small and medium business infrastructure. SMEs from Moldova face a large number of challenges, both on global and local level. The major challenges for Moldavian SMEs are: heavy regulatory framework, lack of diverse financing sources and high costs of infrastructure, global competition and lack of technologic and managerial capabilities. SMEs' development involves a comprehensive solution of the following requirements:

- providing financial support for small business, appropriate to its needs in terms of affordability, volume and timing, which would be achievable by combining efforts of state, banking sector and small businesses alike;

- implementing a selective approach of state support for small businesses depending on their area of activity by applying appropriate tax, financial measures and public contract system as a priority;

- creating "growth poles" on the basis of free economic zones, industry and infrastructure;

- adopting the framework on venture funds and creating a national venture fund, that might be an alternative source of finance for local SMEs;

- developing innovation infrastructure and establishing innovation brokerage centres and connecting them to specialized international networks;

- developing partnerships between research organizations, universities and SMEs.

According to SMEs policy index, for Eastern partner Countries, the Republic of Moldova has made moderate progress in further developing a conducive business environment for SMEs. Moldova has advanced in the implementation of the SME Development Strategy 2012-2020 with substantial progress in the reduction of burdensome regulation, the implementation of regulatory impact analysis and the provision of business development services for SMEs. Noteworthy reforms also include reinforced policy framework for entrepreneurial learning, start-up support for young entrepreneurs, an expansion of the credit guarantee scheme, broadened egovernment services and a formalised public-private dialogue platform.

In future, Moldova should focus on promoting a level playing field for all enterprises through effective competition policy and a transparent and independent 
judiciary. Moldova state should promote and implement survival policies in order to expand dynamic capabilities, establish new partnerships, and develop technology innovation. Considerable work remains to be done to promote entrepreneurial learning, including meeting the specific skills requirements of SMEs. The limited internationalisation of Moldovan SMEs is a long-term challenge. In addition, Moldova could further support the innovation activities of SMEs and their transition to the green economy.

\section{References}

- $\quad$ Asare, R., Akuffobea, M., Quaye, W. \& Atta-Antwi, K., 2015. Characteristics of Micro, Small and Medium Enterprises in Ghana: Gender and Implications for Economic Growth. African Journal of Science, Technology, Innovation and Development, 7(1), pp. 26-35.

- European Commission,(2020).'Small business act for Europe'.[Online].European Commission.[Retrieved May 29,2021], http://ec.europa.eu/enterprise/polici es/sme/small-business-act/.

- Erhan, L. (2009),'Financial strategies for the development of small and medium-sized enterprises through ensuring a functional market economy. PhD thesis in economics at the specialty 08.00.10. - Finance; currency; credit'. [Online], National Council for Accreditation and Attestation from Republic of Moldova
[Retrieved

April

27,2021],http://www.cnaa.md/files/t heses/2013/25306/lica erhan thesis. pdf

- Government of Republic of Moldova. (13.09.2012). 'Strategy of small and medium sized enterprises sector for 2012-2020 nr.685'.[On-line]. Government of Republic of Moldova.[Retrieved July 15,2020], http://green.gov.md/

- International Monetary Fond, Tehnical Assistance Report (2021) report. 'Republic of Moldova Country Governance Assessment'. [On-line]. $I M F$.[Retrieved June 15, 2020], https://www.ifc.org/

- National Bureau of Statistics of Republic of Moldova. (2020).[Online]. National Bureau of Statistics of Republic of Moldova.[Retrieved May 16,2021], www.statistica.md.

- Munro, D., 2013. A Guide to Financing SMEs. New York, USA: Palgrave Macmillan.

- World Economic Forum (2019), The Global Competitiveness Report 2019, World Economic Forum, Geneva, [Retrieved July 16,2021], http://reports.weforum.org/globalcompetitiveness-report-2019/.

- World Bank (2019), Doing Business 2020, World Bank, Washington, DC, [Retrieved July 19, 2021], http://www.doingbusiness.org/en/d oingbusiness. 